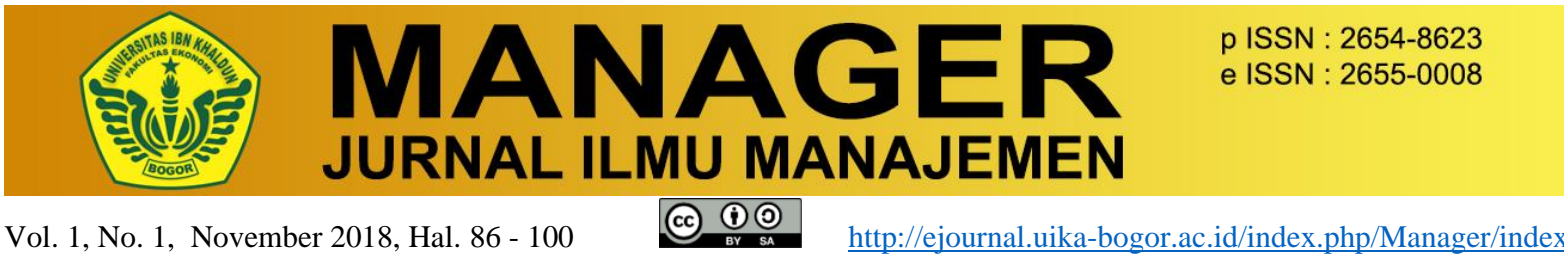

\title{
Analisis Sistem Du Pont Untuk Mengukur Kinerja Keuangan \\ Perusahaan
}

\author{
Shabri Indrawan, Budihardjo,Titing Suharti. \\ Fakultas Ekonomi dan Bisnis Universitas Ibn Khaldun Bogor, Indonesia
}

\begin{abstract}
ABSTRAK
Penelitian ini ditujukan untuk mengetahui kinerja keuangan perusahaan yang terdaftar di Bursa Efek Indonesia (BEI) periode 2012-2016 sektor makanan. Penelitian adalah untuk mengukur kinerja keuangan dengan menggunakan hasil dari analisis du pont yaitu asset turn over, net profit margin, return on investment, equity multiplier, dan return on equity. Penelitian ini menggunakan jenis data kuantitaif, dan data yang digunakan adalah data sekunder dengan teknik pengumpulan data studi pustaka dan dokumentasi. Hasil perhitungan dengan menggunakan analisis sistem Du Pont, Return On Equity (ROE) diperoleh bahwa PT Mayora Indah Tbk yang menghasilkan Return On Equity tertinggi dibanding dengan PT Indofood Sukses Makmur Tbk. dan dari hasil perhitungan Return On Investment (ROI) dan Return On Equity (ROE), PT Indofood Sukses Makmur Tbk dan PT Mayora Indah Tbk, mengalami fluktuatif setiap tahunnya.

Kata Kunci : Du Pont, Kinerja Keuangan,Perusahaan
\end{abstract}

\section{I.Pendahuluan}

\section{Latar Belakang Penelitian}

Dalam perekonomian yang semakin berkembang seperti saat ini, terjadi persaingan yang sulit dalam berbagai bidang bisnis, oleh karena itu perusahaan dituntut untuk bisa bertahan dalam persaingan bisnis apapun. Suatu perusahaan harus memperhitungkan langkah-langkah yang akan di jalankan untuk mempertahankan kelangsungan hidup perusahaan, salah satunya analisis laporan keuangan perusahaan. Analisis laporan keuangan pada perusahaan sangat bermanfaat untuk mengetahui keadaan dan perkembangan keuangan dari perusahaan saat itu.masalah keuangan merupakan salah satu masalah yang sangat penting bagi sebuah perusahaan. Karena pada dasarnya perusahaan didirikan untuk memaksimalkan nilai perusahaan 
tersebut, sehingga perusahaan dituntut untuk mendapatkan pangsa pasar yang lebih luas, namun dapat memanfaatkan barang modal secara efisien.

Dengan keadaan perekonomian yang semakin melemah berdampak pula pada keuangan perusahaan, sehingga menuntut perusahan untuk segera memulihkan kondisi keuangan perusahaan pada periode yang akan datang. Dalam melihat atau menilai kesehatan dan prestasi perusahaan di bidang keuangan dapat melihat dari macam-macam rasio yang dapat memberikan pandangan tentang prestasi perusahaan dalam bidang keuangan.Hal ini dilakukan untuk dapat mengetahui perusahaan tersebut memiliki kinerja yang baik atau tidak.

$\begin{array}{llr}\text { Untuk } & \text { mengetahui } & \text { kondisi } \\ \text { keuangan } & \text { perusahaan } & \text { yang }\end{array}$
bersangkutan dapat dilakukan dengan menganalisa laporan keuangan. Laporan keuangan perusahaan adalah sebagai sumber informasi untuk berbagai kepentingan manajemen, seperti dalam pengambilan keputusan investasi di pasar modal. Perusahaan juga dapat mengefisiensi biaya-biaya yang di keluarkan oleh perusahaan dalam menjalankan oprasional perusahaan. Laporan keuangan juga dapat digunakan untuk mendeteksi tingkat kesehatan perusahaan, melalui analisis kondisi arus kas atau kinerja organisasi perusahaan. Laporan keuangan sendiri pada umumnya terdiri dari neraca dan laporan laba-rugi. Neraca merupakan laporan keuangan yang memberikan informasi posisi keuangan perusahaan pada saat tertentu yang disusun secara sistematis.
Dalam penelitian ini untuk menganalisis kinerja perusahaan digunakan Analisis Du Pont. Analisis Du Pont akan memberikan gambaran tentang seberapa jauh kinerja keuangan pada suatu perusahaan dan bagaimana tingkat prestasi perusahaan dalam menghasilkan laba. Analisis ini juga bersifat menyeluruh karena tidak hanya menghitung laba yang diperoleh perusahaan atas produksinya tetapi mencakup tingkat efisiensi dan mengukur tingkat keuntungan perusahaan.

Dalam sistem ini memiliki beberapa faktor yang berpengaruh untuk mengetahui kinerja keuangan perusahaan, faktor-faktor ini saling berhubungan pada tingkat pengambilan atas Return On Invesment (ROI) dan Return On Equity (ROE) yaitu margin laba bersih, perputaran aktiva dan tingkat hutang.

Dalam analisis sistem Du Pont memfokuskan juga investasi yang dapat menghasilkan laba. Dapat dikatakan juga besar dan kecilnya tingkat Return On Invesment (ROI) dan Return On Equity (ROE) berpengaruh terhadap laba perusahaan. Jika ROI (Return On Invesment) dan ROE (Return On Equity) yang dihasilkan perusahaan lebih besar maka semakin baik pula kinerja perusahaan dalam memperoleh laba.

\section{Rumusan Masalah}

Berdasarkan latar belakang yang telah diuraikan maka, rumusan masalah dari penulisan penelitian ini adalah bagaimana kinerja keuangan pada PT. Indofood Sukses Makmur Tbk dan PT. Mayora Indah Tbk Selama periode 2012 
- 2016 dengan menggunakan Sistem Du Pont?

\section{Tujuan Penelitian}

Tujuan dari Penelitian ini adalah untuk mengetahui kinerja keuangan

\section{II.Tinjauan Pustaka}

\section{Analisis Sistem Du Pont}

Menurut Bambang Wahyudiono (2014:91) analisis Du Pont adalah "analisis rasio yang memusatkan analisis pada bagaimana meningkatkan ROE atau Return On Equity".

Analisis Du Pont Sistem merupakan analisis yang digunakan untuk mengontrol perubahan dalam rasio aktivitas dan net profit margin dan seberapa besar pengaruhnya terhadap ROI atau Return On Investment.

Dengan demikian, analisis Du Pont Sistem merupakan analisis yang mencakup rasio aktivitas dan margin keuntungan atas penjualan untuk menentukan profitabilitas yang dimiliki perusahaan. Sistem Du pont dan sistem rentabilitas ekonomi mempunyai kemiripan sehingga sering ditafsirkan sama. Pada sistem Du Pont dalam menghitung Return On Investment (ROI) yang ditafsirkan sebagai laba adalah laba setelah pajak, sedangkan pada konsep rentabilitas ekonomi laba yang dimaksud adalah laba sebelum bunga dan pajak. Sedangkan pembagiannya sama yaitu investasi atau total aktiva.

\section{Alat Analisis Du Pont}

Menurut Arif Sugiono (2009:86) alat analisis yang digunakan dalam Sistem Du Pont adalah sebagai berikut: menggunakan Sistem Du Pont pada PT. Indofood Sukses Makmur Tbk dan PT. Mayora Indah Tbk Selama periode 2012 $-2016$.

\section{Asset Turn Over}

Asset Turn Over menunjukan kemampuan perusahaan dalam mengelola investasi untuk menghasilkan penjualan.

$$
\text { Asset Turn Overn }=\frac{\text { Penjualan }}{\text { Total Aktiva }}
$$

2. Net Profit Margin (Return On sales)

Net Profit Margin (return on sales) menunjukan seberapa besar keuntungan bersih yang diperoleh perusahaan.

Net Profit Margin $=\frac{\text { Laba Bersih }}{\text { Penjualan }}$

\section{Return On Investment (ROI)}

Rasio ini mengukur tingkat pembelian dari bisnis atas seluruh asset yang ada.

$$
\begin{aligned}
\mathrm{ROI}= & \text { Net Profit Margin } \mathrm{x} \text { Asset } \\
& \text { Turn Over }
\end{aligned}
$$

4. Equity Multiplier (Asset Laverage) Asset laverage merupakan atau sering juga disebut dengan penggandan ekuitas (equity multiplier), menggambarkan 
seberapa besar ekuitas atau modal jika dibandingkan dengan total aktiva perusahaan atau seberapa besar aktiva dibiayai oleh hutang.

Equity Multiplier $=\frac{\text { Total } \text { Aktiva }}{\text { Total Ekuitas }}$
Rasio ini mengukur tingkat pengembalian dari bisnis atas seluruh modal yang ada. ROE dalam Du Pont Sistem hitung dengan mengalikan ROI dengan Equity Multiplier.

5. Retur On Equity (ROE)

ROE $=$ ROI $x$ Equity Multiplier

Gambar 1.

\section{Flow Chart Analisis Du Pont}

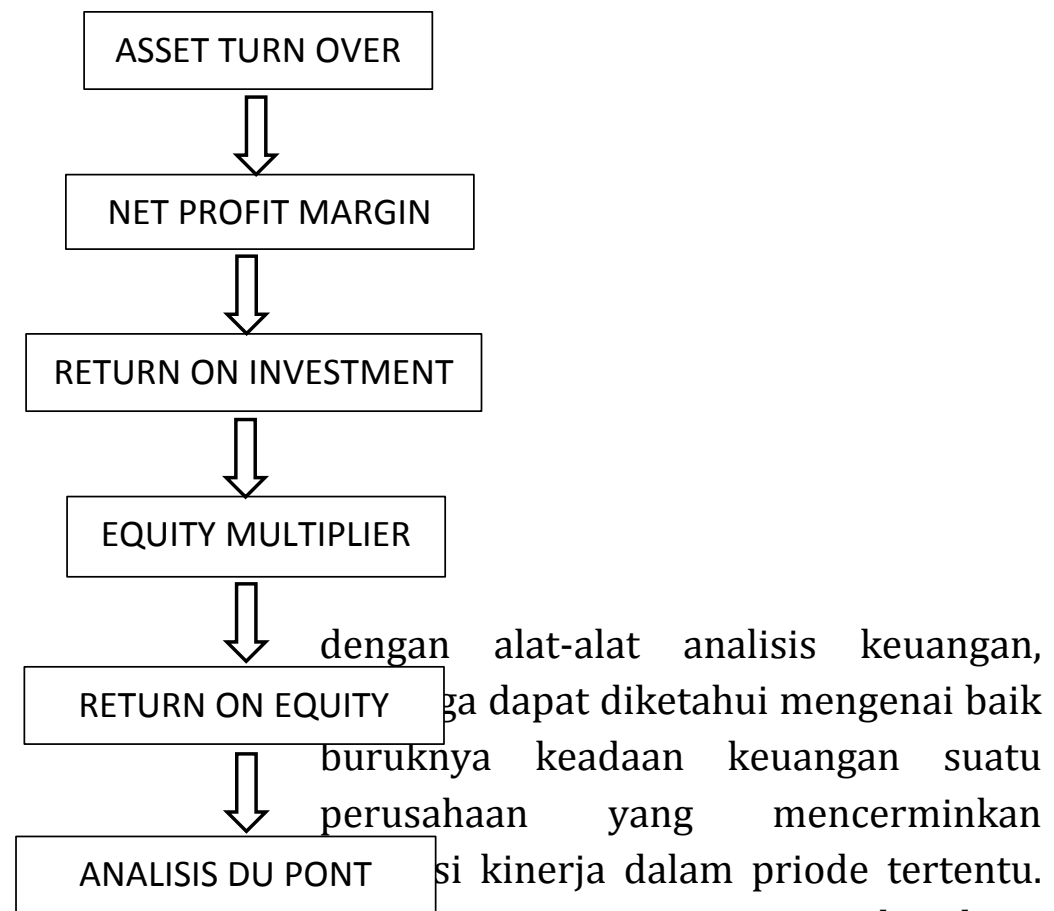

Hal inı sangat penting agar sumber daya

\section{Kinerja Keuangan}

Kinerja perusahaan merupakan suatu gambaran tentang kondisi keuangan suatu perusahaan yang dianalisis 
digunakan secara optimal dalam menghadapi perubahan lingkungan. Menurut Arif Sugiono, (2009:65) dalam bukunya manajemen keuangan untuk praktisi keuangan, mengatakan bahwa dari segi manajemen keuangan, perusahaan dikatakan mempunyai kinerja yang baik atau tidak dapat diukur dengan :

\section{IV.Pembahasan dan Hasil}

Analisis Du Pont Pada PT. Indofood Sukses Makmur Tbk dan PT. Mayora Indah Tbk.

\section{PT. Indofood Sukses Makmur Tbk}

1. Asset Turn Over PT. Indofood Sukses Makmur Tbk

$$
\text { Asset Turn Over }=\frac{\text { Penjualan }}{\text { Total Aktiva }} \times 1 \text { Kali }
$$

Hasil perhitungan Asset Turn Over tabel pada PT. Indofood Sukses Makmur Tbk Tbk tahun 2012 - 2016 (Dinyatakan dalam Jutaan Rupiah)

Tabel 1

Asset Turn Over PT. Indofood Sukses Makmur tahun 2012 - 2016

(Dinyatakan dalam Jutaan Rupiah)

\begin{tabular}{|c|c|c|c|c|}
\hline Tahun & Penjualan & Total Aktiva & Asset Turn Over & $\begin{array}{c}\text { Perubahan (\%) } \\
\text { Naik/(Turun) }\end{array}$ \\
\hline 2012 & 50.059 .427 & 59.324 .207 & $0,84 \mathrm{Kali}$ & - \\
\hline 2013 & 57.731 .998 & 78.092 .789 & $0,74 \mathrm{Kali}$ & $(0,10)$ \\
\hline 2014 & 63.594 .452 & 85.938 .885 & $0,74 \mathrm{Kali}$ & 0 \\
\hline 2015 & 64.061 .947 & 91.831 .526 & $0,70 \mathrm{Kali}$ & $(0,04)$ \\
\hline 2016 & 66.750 .317 & 82.174 .515 & $0,81 \mathrm{Kali}$ & 0,11 \\
\hline
\end{tabular}

\section{Sumber : Data diolah}

Berdasarkan tabel hasil analisis di atas, maka dapat diketahui asset turn over tahun 2012 adalah 0,84 kali, artinya perusahaan mampu memutar aset $\mathrm{Rp}$ 1,00 sebanyak 0,84 kali dalam penjualan. Pada tahun 2013 mengalami penurunan sebesar 0,10 kali menjadi 0,74 kali, hal ini disebabkan karena penjualan tidak sebanding dengan kenaikan total aktiva. Pada tahun 2014 
masih sama dengan tahun 2013 yaitu sebesar 0,74 kali. Pada tahun 2015 mengalami penurunan sebesar 0,04 kali menjadi 0,70 kali, hal ini disebabkan karena penjualan yang masih tidak sebanding dengan kenaikan total aktiva. Pada tahun 2016 mengalami kenaikan

2. Net Profit Margin PT. Indofood Sukses Makmur Tbk sebesar 0,11 kali menjadi 0,81 kali, hal ini disebabkan karena penjualan mengalami kenaikan sementara total aktiva mengalami penurunan yang tidak jauh dari tahun sebelumnya yaitu tahun 2015.

$$
\text { Net Profit Margin }=\frac{\text { Laba Bersih }}{\text { Penjualan }} \times 100 \%
$$

Hasil perhitungan Net Profit Margin tabel pada PT. Indofood Sukses Makmur tahun 2012 - 2016 (Dinyatakan dalam Jutaan Rupiah):

Tabel 2

Net Profit Margin PT. Indofood Sukses Makmur tahun 2012 - 2016

(Dinyatakan dalam Jutaan Rupiah)

\begin{tabular}{|c|c|c|c|c|}
\hline Tahun & Laba Bersih & Penjualan & Net Profit Margin & $\begin{array}{c}\text { Perubahan (\%) } \\
\text { Naik/(Turun) }\end{array}$ \\
\hline 2012 & 4.779 .446 & 50.059 .427 & $9,55 \%$ & - \\
\hline 2013 & 3.416 .635 & 57.731 .998 & $5,92 \%$ & 2,17 \\
\hline 2014 & 5.146 .323 & 63.594 .452 & $8,09 \%$ & $(2,30)$ \\
\hline 2015 & 3.709 .501 & 64.061 .947 & $5,79 \%$ & 2,10 \\
\hline 2016 & 5.226 .906 & 66.750 .317 & $7,89 \%$ & \\
\hline
\end{tabular}

Sumber : Data diolah

Net Profit Margin tahun 2012 menunjukan angka $9,55 \%$ yang menggambarkan bahwa dari penjualan sebesar Rp 1,00 perusahaan memperoleh laba bersih sebesar $\mathrm{Rp}$ 0,0955 atau 9,55\%. Pada tahun 2013 mengalami penurunan sebesar 3,63\% menjadi 5,92\%, hal ini disebabkan karena laba bersih mengalami penurunan sementara penjualan mengalami kenaikan. Pada tahun 2014 mengalami kenaikan sebesar 2,17\% menjadi 8,09\%, hal ini disebakan karena laba bersih mengalami kenaikan sedangkan penjualan juga mengalami kenaikan. Pada tahun 2015 mengalami penurunan kembali sebesar 2,30\% menjadi 5,79\%, hal ini disebabkan karena laba bersih mengalami penurunan sedangkan penjualan mengalami kenaikan. Pada tahun 2016 mengalami kenaikan sebesar 2,10\% menjadi 7,89\%, hal ini disebakan karena laba bersih mengalami kenaikan sedangkan penjualan juga mengalami kenaikan

3. Return On Investment (ROI) PT. Indofood Sukses Makmur 
Hasil perhitungan Return On Investment tabel pada PT. Indofood Sukses Makmur tahun 2012 - 2016:

Tabel 3

Return On Investment PT. Indofood Sukses Makmur tahun 2012 - 2016

(Dinyatakan dalam Jutaan Rupiah)

\begin{tabular}{|c|c|c|c|c|}
\hline Tahun & Net Profit Margin & Asset Turn Over & $\begin{array}{c}\text { Return On } \\
\text { Investment }\end{array}$ & $\begin{array}{c}\text { Perubahan (\%) } \\
\text { Naik/(Turun) }\end{array}$ \\
\hline 2012 & $9,55 \%$ & $0,84 \mathrm{Kali}$ & $8,02 \%$ & - \\
\hline 2013 & $5,92 \%$ & $0,74 \mathrm{Kali}$ & $4,38 \%$ & $(3,64)$ \\
\hline 2014 & $8,09 \%$ & $0,74 \mathrm{Kali}$ & $5,99 \%$ & 1,61 \\
\hline 2015 & $5,79 \%$ & $0,70 \mathrm{Kali}$ & $4,05 \%$ & $(1,94)$ \\
\hline 2016 & $7,89 \%$ & $0,81 \mathrm{Kali}$ & $6,39 \%$ & 2,34 \\
\hline
\end{tabular}

Sumber : Data diolah

Return On Investment pada tahun 2012 menunjukan angka 8,02\%, yang artinya bahwa perusahaan mampu mengelola setiap aset Rp 1,00 untuk menghasilkan keuntungan sebesar Rp 0,0802 atau 8,02\%. Pada tahun 2013 mengalami penurunan sebesar $3,64 \%$ menjadi 4,38\%, hal ini disebabkan karena net profit margin dan asset turn over mengalami penurunan. Pada tahun 2014 mengalami kenaikan sebesar $1,61 \%$ menjadi 5,99\%, hal ini disebabkan karena net profit margin

4. Equity Multiplier PT. Indofood Sukses Makmur

$$
\text { Equity Multiplier }=\frac{\text { Total Aktiva }}{\text { Total Equity }} \times 1 \text { Kali }
$$

Tabel 4

Equity Multiplier PT. Indofood Sukses Makmur Tbk tahun 2012 - 2016

(Dinyatakan dalam Jutaan Rupiah)

\begin{tabular}{|c|c|c|c|c|}
\hline Tahun & Total Aktiva & Total Ekuitas & Equity Multiplier & $\begin{array}{c}\text { Penurunan (\%) } \\
\text { Naik/(Turun) }\end{array}$ \\
\hline 2012 & 59.324 .207 & 34.142 .674 & $1,74 \mathrm{Kali}$ & - \\
\hline 2013 & 78.092 .789 & 38.373 .129 & $2,04 \mathrm{Kali}$ & 0,30 \\
\hline 2014 & 85.938 .885 & 41.228 .376 & $2,08 \mathrm{Kali}$ & 0,04 \\
\hline
\end{tabular}




\begin{tabular}{|c|c|c|c|c|}
\hline 2015 & 91.831 .526 & 43.121 .593 & 2,13 Kali & 0,05 \\
\hline 2016 & 82.174 .515 & 43.941 .423 & 1,87 Kali & $(0,26)$ \\
\hline
\end{tabular}

Sumber : Data diolah

Hasil perhitungan analisis menunjukan Equity Multiplier tahun 2012 menunjukan angka 1,74 kali, yang artinya bahwa besarnya aktiva perusahaan dibiayai oleh hutang sebesar 1,74 kali. Pada tahun 20132015 mengalami kenaikan masingmasing 0,30 kali menjadi 2,04 kali pada tahun 2013, sebesar 0,04 kali menjadi 2,08 kali pada tahun 2014, pada tahun
2015 sebesar 0,05 kali menjadi 2,13 kali, hal ini disebabkan karena total aktiva mengalami kenaikan dan total ekuitas juga mengalami kenaikan dari tahun 2013 - 2015. Sedangkan pada tahun 2016 mengalami penurunan sebesar 0,26 kali menjadi 1,87 kali, hal ini disebabkan karena total aktiva mengalami penurunan sementara total ekuitas naik

5. Return On Equity (ROE) PT. Indofood Sukses Makmur

ROE = Return On Investment X Equity Multiplier

Hasil perhitungan Return On Investment tabel pada PT. Indofood Sukses Makmur tahun 2012 - 2016 (Dinyatakan dalam Jutaan Rupiah)

Tabel 5

Return On Equity PT. Indofood Sukses Makmur Tbk tahun 2012 - 2016

(Dinyatakan dalam Jutaan Rupiah)

\begin{tabular}{|c|c|c|c|c|}
\hline Tahun & $\begin{array}{c}\text { Return On } \\
\text { Investment }\end{array}$ & Equity Multiplier & Return On Equity & $\begin{array}{c}\text { Perubahan (\%) } \\
\text { Naik/(Turun) }\end{array}$ \\
\hline 2012 & $8,02 \%$ & $1,74 \mathrm{Kali}$ & $13,95 \%$ & - \\
\hline 2013 & $4,38 \%$ & $2,04 \mathrm{Kali}$ & $8,94 \%$ & $(5,01)$ \\
\hline 2014 & $5,99 \%$ & $2,08 \mathrm{Kali}$ & $12,46 \%$ & 3,52 \\
\hline 2015 & $4,05 \%$ & $2.13 \mathrm{Kali}$ & $8,63 \%$ & $(3,83)$ \\
\hline 2016 & $6,39 \%$ & $1,87 \mathrm{Kali}$ & $11,95 \%$ & 3,32 \\
\hline
\end{tabular}

Sumber : Data diolah

Return On Equity tahun 2012 menunjukan angka 13,95\%, artinya tingkat pengembalian bisnis atau seluruh modal yang ada adalah sebesar 13,95\%. Pada tahun 2013 mengalami penurunan sebesar $5,01 \%$ menjadi 8,94\%, hal ini disebabkan karena return on investment mengalami penurunan sedangkan equity multiplier mengalami kenaikan. Pada tahun 2014 mengalami kenaikan sebesar 3,52\% menjadi $12,46 \%$, hal ini disebabkan karena return on investment dan equity multiplier mengalami kenaikan. Pada tahun 2015 mengalami penurunan sebesar 3,83\% menjadi $8,63 \%$, hal ini disebabkan karena return on investment mengalami penurunan sedangkan equity multiplier naik. Pada tahun 2016 mengalami kenaikan sebedar 3,32\% 
menjadi 11,95\%, hal ini disebabkan karena return on investment naik sedangkan equity multiplier mengalami penurunan.

Tabel 6

Hasil Perhitungan Sistem Du Pont

PT. Indofood Sukses Makmur

Periode 31 Desember 2012 s/d 2016

\begin{tabular}{|c|c|c|c|c|c|}
\hline Keterangan & $\begin{array}{c}\text { Asset Turn } \\
\text { Over }\end{array}$ & $\begin{array}{c}\text { Net Profit } \\
\text { Margin }\end{array}$ & $\begin{array}{c}\text { Return On } \\
\text { Investment }\end{array}$ & $\begin{array}{c}\text { Equity } \\
\text { Multiplier }\end{array}$ & $\begin{array}{c}\text { Return On } \\
\text { Equity }\end{array}$ \\
\hline 2012 & $0,84 \mathrm{Kali}$ & $9,55 \%$ & $8,02 \%$ & $1,74 \mathrm{Kali}$ & $13,95 \%$ \\
\hline 2013 & $0,74 \mathrm{Kali}$ & $5,92 \%$ & $4,38 \%$ & $2,04 \mathrm{Kali}$ & $8,94 \%$ \\
\hline 2014 & $0,74 \mathrm{Kali}$ & $8,09 \%$ & $5,99 \%$ & $2,08 \mathrm{Kali}$ & $12,46 \%$ \\
\hline 2015 & $0,70 \mathrm{Kali}$ & $5,79 \%$ & $4,05 \%$ & $2.13 \mathrm{Kali}$ & $8,63 \%$ \\
\hline 2016 & $0,81 \mathrm{Kali}$ & $7,89 \%$ & $6,39 \%$ & $1,87 \mathrm{Kali}$ & $11,95 \%$ \\
\hline Rata - rata & $0,77 \mathrm{Kali}$ & $7,45 \%$ & $5,77 \%$ & $1,97 \mathrm{Kali}$ & $11,19 \%$ \\
\hline
\end{tabular}

Sumber : Data diolah

\section{PT. Mayora Indah Tbk}

1. Asset Turn Over PT. Mayora Indah Tbk

$$
\text { Asset Turn Over }=\frac{\text { Penjualan }}{\text { Total Aktiva }} \times 1 \text { Kali }
$$

Hasil perhitungan Asset Turn Over tabel pada PT. Mayora Indah Tbk tahun 2012 - 2016 (Dinyatakan dalam Rupiah):

Tabel 7

Asset Turn Over PT. Mayora Indah Tbk tahun 2012 - 2016

(Dinyatakan dalam Rupiah)

\begin{tabular}{|c|c|c|c|c|}
\hline Tahun & Penjualan & Total Aktiva & $\begin{array}{l}\text { Asset } \\
\text { Turn } \\
\text { Over }\end{array}$ & $\begin{array}{c}\text { Perubahan (\%) } \\
\text { Naik / Turun }\end{array}$ \\
\hline 2012 & 10.510 .625 .669 .832 & 8.302 .506 .241 .903 & $\begin{array}{l}1,27 \\
\text { Kali }\end{array}$ & - \\
\hline 2013 & 12.017 .837 .133 .337 & 9.709 .838 .250 .473 & $\begin{array}{l}1,24 \\
\text { Kali }\end{array}$ & $(0,03)$ \\
\hline 2014 & 14.169 .088 .278 .238 & 10.291 .108 .029 .334 & $\begin{array}{l}1,38 \\
\text { Kali }\end{array}$ & 0,14 \\
\hline 2015 & 14.818 .730 .635 .847 & 11.342 .715 .686 .221 & $\begin{array}{l}1,31 \\
\text { Kali }\end{array}$ & $(0,07)$ \\
\hline 2016 & 18.349 .959 .898 .358 & 12.992 .421 .859 .142 & 1,41 & 0,10 \\
\hline
\end{tabular}




\begin{tabular}{|l|l|l|l|l|}
\hline & & & Kali & \\
\hline
\end{tabular}

Sumber : Data diolah

Berdasarkan tabel analisis hasil di atas, maka dapat diketahui asset turn over tahun 2012 adalah 1,27 kali, artinya perusahaan mampu memutar setiap aset $\mathrm{Rp}$ 1,00 sebanyak 1,27 kali dalam penjualan. Pada tahun 2013 mengalami penurunan sebesar 0,03 kali menjadi 1,24 kali, hal ini disebabkan karena kenaikan penjualan pada tahun 2013 tidak sebanding dengan kenaikan total aktiva. Pada tahun 2014 mengalami kenaikan sebesar 0,14 kali menjadi 1,38kali, hal ini disebabkan karena penjualan mengalami kenaikan sementara total aktiva juga mengalami kenaikan. Pada tahun 2015 mengalami penurunan sebesar 0,07 kali menjadi 1,31 kali, hal ini disebabkan karena penjualan tidak sebanding dengan kenaikan total aktiva. Pada tahun 2016 mengalami kenaikan sebesar 0,10 kali menjadi 1,41 kali, hal ini disebabkan karena penjualan mengalami kenaikan sementara total aktiva juga mengalami kenaikan

2. Net Profit Margin PT. Mayora Indah Tbk

$$
\text { Net Profit Margin }=\frac{\text { Laba Bersih }}{\text { Penjualan }} \times 100 \%
$$

Hasil perhitungan Net Profit Margin tabel Pada PT. Mayora Indah Tbk tahun 2012 2016 (Dinyatakan dalam Rupiah):

Tabel 8

Net profit Margin PT. Mayora Indah Tbk tahun 2012- 2016

(Dinyatakan dalam Rupiah)

\begin{tabular}{|c|l|l|c|c|}
\hline Tahun & \multicolumn{1}{|c|}{ Laba Bersih } & Penjualan & $\begin{array}{c}\text { Net Profit } \\
\text { Margin }\end{array}$ & $\begin{array}{c}\text { Perubahan (\%) } \\
\text { Naik/(Turun) }\end{array}$ \\
\hline 2010 & 744.428 .404 .309 & 10.510 .625 .669 .832 & $7,08 \%$ & - \\
\hline 2011 & 1.058 .418 .939 .252 & 12.017 .837 .133 .337 & $8,81 \%$ & 1,73 \\
\hline 2012 & 409.824 .768 .594 & 14.169 .088 .278 .238 & $2,89 \%$ & $(5,92)$ \\
\hline 2013 & 1.250 .233 .128 .560 & 14.818 .730 .635 .847 & $8,44 \%$ & 5,55 \\
\hline 2014 & 1.388 .676 .127 .665 & 18.349 .959 .898 .358 & $7,57 \%$ & $(0,87)$ \\
\hline
\end{tabular}

Sumber : Data diolah

Net Profit Margin tahun 2012 menunjukan angka 7,08\%, yang artinya dari penjualan $\mathrm{Rp} 1,00$ perusahaan memperoleh laba bersih sebesar $\mathrm{Rp}$ 0,0708 atau 7,08\%. Pada tahun 2013 mengalami kenaikan sebesar 1,73\% menjadi 8,81\%, hal ini disebabkan karena laba bersih mengalami kenaikan sedangkan penjualan juga mengalami kenaikan. Pada tahun 2014 mengalami penurunan sebesar 5,92\% menjadi 2,89, hal ini disebabkan karena laba bersih mengalami penurunan sedangkan penjualan mengalami kenaikan. Pada tahun 2015 mengalami kenaikan sebesar 5,55\% menjadi 8,44\%, hal ini disebabkan karena laba bersih dan penjualan mengalami kenaikan. Pada tahun 2016 mengalami penurunan sebesar $0,87 \%$ menjadi $7,57 \%$, hal ini 
disebabkan karena kenaikan laba bersih

kenaikan.

tidak sebanding dengan penjualan yang

3. Return On Investment (ROI) PT. Mayora Indah Tbk

ROI = Net Profit Margin X Asset Turn Over

Hasil perhitungan Return On Investment tabel pada PT. Mayora Indah Tbk Tbk tahun 2012 - 2016:

Tabel 9

Return On Investment PT. Mayora Indah Tbk tahun 2012 - 2016

(Dinyatakan dalam Rupiah)

\begin{tabular}{|c|c|c|c|c|}
\hline Tahun & Net Profit Margin & Asset Turn Over & $\begin{array}{c}\text { Return On } \\
\text { Investment }\end{array}$ & $\begin{array}{c}\text { Perubahan (\%) } \\
\text { Naik/ (Turun) }\end{array}$ \\
\hline 2012 & $7,08 \%$ & 1,27 Kali & $8,99 \%$ & - \\
\hline 2013 & $8,81 \%$ & $1,24 \mathrm{Kali}$ & $10,92 \%$ & 1,93 \\
\hline 2014 & $2,89 \%$ & $1,38 \mathrm{Kali}$ & $3,99 \%$ & $(6,93)$ \\
\hline 2015 & $8,44 \%$ & $1,31 \mathrm{Kali}$ & $11,06 \%$ & 7,07 \\
\hline 2016 & $7,57 \%$ & $1,41 \mathrm{Kali}$ & $10,67 \%$ & $(0,39)$ \\
\hline
\end{tabular}

Sumber : Data diolah

Return On Investment pada tahun 2012 menunjukan angka 8,99\%, yang artinya bahwa perusahaan mampu mengelola setiap aset Rp 1,00 untuk menghasilkan keuntungan sebesar $\mathrm{Rp}$ 0,0899 atau 8,99\%. Pada tahun 2013 mengalami kenaikan 1,93\% menjadi 10,92\% , hal ini disebabkan karena net profit margin mengalami kenaikan sedangkan asset turn over mengalami penurunan. Pada tahun 2014 mengalami penurunan sebesar 6,93\% menjadi 3,99\%, hal ini disebabkan karena net profit margin mengalami penurunan sedangakan asset turn over mengalami kenaikan. Pada tahun 2015 mengalami kenaikan sebesar $7,07 \%$ menjadi $11,06 \%$, hal ini disebabkan karena net profit margin mengalami kenaikan sedangkan asset turn over mengalami penurunan. pada tahun 2016 mengalami penurunan sebesar $0,39 \%$ menjadi $10,67 \%$, hal ini disebabkan karena penurunan net profit margin mengalami penurunan sedangkan asset turn over mengalami kenaikan

4. Equity Multiplier PT. Mayora Indah Tbk

$$
\text { Equity Multiplier }=\frac{\text { Total Aktiva }}{\text { Total Equity }} \times 1 \text { Kali }
$$

Hasil perhitungan Equity Multiplier tabel PT. Mayora Indah Tbk tahun 2012 - 2016 (Dinyatakan dalam Rupiah):

Tabel 9

Equity Multiplier PT. Mayora Indah Tbk tahun 2012 - 2016 
(Dinyatakan dalam Rupiah)

\begin{tabular}{|c|l|l|c|c|}
\hline Tahun & \multicolumn{1}{|c|}{ Total Aktiva } & Total Ekuitas & $\begin{array}{c}\text { Equity } \\
\text { Multiplier }\end{array}$ & $\begin{array}{c}\text { Perubahan (\%) } \\
\text { Naik/(Turun) }\end{array}$ \\
\hline 2012 & 8.302 .506 .241 .903 & 3.067 .850 .327 .238 & 2,71 Kali & - \\
\hline 2013 & 9.709 .838 .250 .473 & 3.938 .760 .819 .650 & 2,47 Kali & $(0,24)$ \\
\hline 2014 & 10.291 .108 .029 .334 & 4.100 .554 .992 .798 & 2,51 Kali & 0,04 \\
\hline 2015 & 11.342 .715 .686 .221 & 5.194 .459 .927 .187 & 2,18 Kali & $(0,33)$ \\
\hline 2016 & 12.992 .421 .859 .142 & 6.265 .255 .987 .065 & 2,07 Kali & $(0,11)$ \\
\hline
\end{tabular}

\section{Sumber : Data diolah}

Equity Multiplier tahun 2012 adalah sebesar 2,71 kali, yang artinya besarnya aktiva perusahaan dibiayai oleh hutang sebesar 2,71 kali. Pada tahun 2013 mengalami penurunan sebesar 0,24 kali menjadi 2,47 kali, hal ini disebabkan karena kenaikan total aktiva tidak sebanding dengan kenaikan total ekuitas. Pada tahun 2014 mengalami kenaikan sebesar 0,04 kali menjadi 2,51 kali, hal ini disebabkan karena total aktiva dan total ekuitas mengalami kenaikan. pada tahun 2015 - 2016 mengalami penurunan masing-masing sebesar 0,33 kali menjadi 2,18 kali pada tahun 2015, sebesar 0,11 kali menjadi 2,07 kali pada tahun 2016, hal ini disebabkan karena kenaikan total aktiva sebanding dengan kenaikan kenaikan total ekuitas.

5. Return On Equity (ROE) PT. Mayora Indah Tbk

ROE = Return On Investment X Equity Multiplier

Hasil perhitungan Return On Equity tabel pada PT. Mayora Indah Tbk tahun
2012 - 2016 (Dinyatakan dalam Rupiah)

Tabel 10

Return On Equity PT. Mayora Indah Tbk tahun 2012 - 2016

(Dinyatakan dalam Rupiah)

\begin{tabular}{|c|c|c|c|c|}
\hline Tahun & $\begin{array}{c}\text { Return On } \\
\text { Investment }\end{array}$ & Equity Multiplier & Return On Equity & $\begin{array}{c}\text { Perubahan (\%) } \\
\text { Naik/(Turun) }\end{array}$ \\
\hline 2012 & $8,99 \%$ & 2,71 Kali & $24,36 \%$ & - \\
\hline 2013 & $10,92 \%$ & 2,47 Kali & $26,97 \%$ & 2,61 \\
\hline 2014 & $3,99 \%$ & 2,51 Kali & $10,01 \%$ & $(16,96)$ \\
\hline 2015 & $11,06 \%$ & 2,18 Kali & $24,11 \%$ & 14,10 \\
\hline 2016 & $10,67 \%$ & 2,07 Kali & $22,09 \%$ & $(2,02)$ \\
\hline
\end{tabular}

Sumber : Data diolah

Return On Equity tahun 2012 sebesar $24,36 \%$, artinya tingkat pengembalian bisnis atau seluruh modal yang ada adalah sebesar 24,36\%. Pada tahun 2013 mengalami kenaikan sebesar $2,61 \%$ menjadi 26,97\%, hal ini disebabkan karena return on investment mengalami kenaikan dan equity multiplier mengalami penurunan. Pada tahun 2014 mengalami penurunan sebesar $16,96 \%$ menjadi $10,01 \%$, hal ini disebabkan karena return on investment mengalami penurunan dan equity multiplier mengalami kenaikan. Pada tahun 2015 mengalami kenaikan sebesar $14,10 \%$ menjadi $24,11 \%$, hal ini 
disebabkan karena return on investment mengalami kenaikan dan equity multiplier mengalami penurunan, dan pada tahun 2016 mengalami penurunan sebesar 2,02\% menjadi 22,09\%, hal ini disebabkan karena return on investment dan equity multiplier mengalami penurunan

Tabel 11

Hasil Perhitungan Sistem Du Pont PT. Mayora Indah Tbk

Periode 31 Desember 2012 s/d 2016

\begin{tabular}{|c|c|c|c|c|c|}
\hline Keterangan & $\begin{array}{c}\text { Asset Turn } \\
\text { Over }\end{array}$ & $\begin{array}{c}\text { Net Profit } \\
\text { Margin }\end{array}$ & $\begin{array}{c}\text { Return On } \\
\text { Investment }\end{array}$ & $\begin{array}{c}\text { Equity } \\
\text { Multiplier }\end{array}$ & $\begin{array}{c}\text { Return On } \\
\text { Equity }\end{array}$ \\
\hline 2012 & $1,27 \mathrm{Kali}$ & $7,08 \%$ & $8,99 \%$ & $2,71 \mathrm{Kali}$ & $24,36 \%$ \\
\hline 2013 & $1,24 \mathrm{Kali}$ & $8,81 \%$ & $10,92 \%$ & $2,47 \mathrm{Kali}$ & $26,97 \%$ \\
\hline 2014 & $1,38 \mathrm{Kali}$ & $2,89 \%$ & $3,99 \%$ & $2,51 \mathrm{Kali}$ & $10,01 \%$ \\
\hline 2015 & $1,31 \mathrm{Kali}$ & $8,44 \%$ & $11,06 \%$ & $2,18 \mathrm{Kali}$ & $24,11 \%$ \\
\hline 2016 & $1,41 \mathrm{Kali}$ & $7,57 \%$ & $10,67 \%$ & $2,07 \mathrm{Kali}$ & $22,09 \%$ \\
\hline Rata - rata & $1,32 \mathrm{Kali}$ & $6,96 \%$ & $9,17 \%$ & $2,39 \mathrm{Kali}$ & $21,51 \%$ \\
\hline
\end{tabular}

Sumber : Data diolah

Hasil Kinerja Keuangan PT Indofood Sukses Makmur Tbk dan PT. Mayora Indah Tbk. Dengan menggunakan Analisis Sistem Du Pont:

1) Asset Turn Over

Berdasarkan analisis sistem du pont pada PT Indofood Sukses Makmur Tbk selama 5 tahun yaitu tahun 2012 - 2016 mampu menghasilkan asset turn over rata-rata 0,77 kali, PT. Mayora Indah Tbk mampu menghasilkan asset turn over rata-rata 1,32 kali, yang dimiliki perusahaan secara efisien untuk menghasilkan penjualan dari total aktiva yang dimiliki.

1) Net Profit Margin

Berdasarkan analisis sistem du pont pada PT Indofood Sukses Makmur Tbk selama 5 tahun yaitu 2012 - 2016 mampu menghasilkan laba bersih setelah pajak dari volume penjualan dengan rata-rata net profit margin sebesar 7,45\%, PT. Mayora Indah Tbk mampu menghasilkan laba bersih setelah pajak dari volume penjualan dengan rata-rata net profit margin sebesar 6,96\%.

2) Return On Invesment (ROI)

Berdasarkan analisis sistem du pont pada PT Indofood Sukses Makmur Tbk selama 5 tahun yaitu tahun 2012 - 2016 mampu menghasilkan laba bersih setelah pajak dari total aktiva dengan rata-rata ROI sebesar 5,77\%, PT. Mayora Indah Tbk mampu menghasilkan laba bersih setelah pajak dari total aktiva dengan rata-rata ROI sebesar 9,17\%, hal ini menunjukan adanya efisiensi dari penggunaan aset perusahaan.

3) Equity Multiplier 
Berdasarkan analisis sistem du pont pada PT Indofood Sukses Makmur Tbk selama 5 tahun yaitu tahun 2012 - 2016 mampu mengelola modal perusahaan dengan rata-rata sebesar 1,97 kali, PT. Mayora Indah Tbk mampu mengelola modal perusahaan dengan rata-rata sebesar 2,39 kali, hal ini untuk menghasilkan pendapatan sehingga mampu meningkatkan aktiva pada perusahaan tersebut.

4) Return On Equity (ROE)

Berdasarkan analisis sistem du pont pada PT Indofood Sukses Makmur Tbk selama 5 tahun yaitu tahun 2012 - 2016 mampu menghasilkan return on equity dengan rata-rata sebesar 11,19\%, PT. Mayora Indah Tbk mampu menghasilkan Return On Equity dengan rata-rata sebesar 21,51\%, hal ini menunjukan bahwa adanya efisiensi penggunaan modal perusahaan.

\section{IV.Kesimpulan Dan Saran}

\section{Kesimpulan}

1. Hasil Perhitungan Analisis Sistem Du Pont

(1) PT Indofood Sukses Makmur Tbk

Berdasarkan hasil perhitungan Asset Turn Over dari tahun 2012 sampai dengan 2016, hasil perhitungan Asset Turn Over tertinggi berada pada tahun 2012sebesar 0,84 kali, hasil perhitungan Net Profit Margin tertinggi pada tahun 2012 sebesar 9,55\%, hasil perhitungan Return On investment tertinggi pada tahun 2012 sebesar 8,02\%, hasil perhitungan Equity Multiplier tertinggi pada tahun 2015 sebesar 2,13 kali, dan hasil perhitungan Return On Equity tertinggi berada pada tahun 2012 sebesar 13,95\%.

(2) PT Mayora Indah Tbk

Berdasarkan hasil perhitungan Asset Turn Over dari tahun 2012 sampai dengan 2016, perhitungan Asset Turn Over tertinggi berada pada tahun 2016 sebesar 1,41 kali, hasil perhitungan Net Profit Margin tertinggi pada tahun 2013 sebesar 8,81\%, hasil perhitungan Return On Investment tertinggi pada tahun 2015 sebesar11,06\%, hasil perhitungan Equity Multiplier tertinggi pada tahun 2012 sebesar 2,71 kali, dan hasil perhitungan Return On Equity tertinggi pada tahun 2013 sebesar 26,97\%.

2. Peranan Analisis Sistem Du Pont pada PT. Indofood Sukses Makmur Tbk dan PT. Mayora Indah Tbk, merupakan alat untuk mengukur kinerja perusahaan dalam mengelola modalnya yang bersumber dari pinjaman maupun dari modal sendiri untuk dikelola, sehingga menghasilkan laba perusahaan yang tinggi dengan biaya operasional yang efisien. Hasil perhitungan dengan menggunakan analisis sistem Du Pont, Return On Equity (ROE) diperoleh informasi bahwa PT 
Mayora Indah Tbk yang menghasilkan Return On Equity tertinggi dibanding dengan PT Indofood Sukses Makmur Tbk.

\section{Saran}

Berdasarkan hasil analisis sistem Du Pont maka penulis memberikan saran kepada perusahaan yang menjadi objek penelitian yaitu PT . Indofood Sukses Makmur Tbk dan PT. Mayora Indah Tbk.

Dilihat dari hasil perhitungan Return On Investment (ROI) dan Return On Equity (ROE), PT Indofood Sukses Makmur Tbk dan PT Mayora Indah Tbk, mengalami fluktuatif setiap tahunnya, agar nilai ROI dan ROE perusahaan naik bisa meningkat marjin laba bersih dengan meminimalisasi biaya operasional, admistrasi maupun mencari produksi serta mencari alternatif pemasaran yang tepat sehingga mampu meningkatkan penjualan.

Saran untuk penelitian selanjutnya:

1) Diharapkan dapat menambahkan analisis lain sebagai perbandingan hasil analisis kinerja keuangan perusahaan.

2) Diharapkan dapat menambah objek dan periode penelitian yang diteliti lebih banyak lagi dengan tujuan memperoleh hasil yang lebih baik.

\section{DAFTAR PUSTAKA}

Sugiono, A. (2009). Manajemen Keuangan Untuk Praktisi Keuangan. Jakarta: Grasindo.

Wahyudiono, B. (2014). Mudah Membaca Laporan Keuangan. Edisi Pertama. 